\title{
EFEKTIVITAS PEMBELAJARAN BERBASIS MASALAH UNTUK MENINGKATKAN SIKAP BERPIKIR KRITIS SISWA SEKOLAH DASAR
}

\author{
Haifaturrahmah, Yuni Maryati", , Sukron Fujiaturrahman \\ Pendidikan Guru Sekolah Dasar, Universitas Muhammadiyah Mataram, aiman@ummat.ac.id
}

\section{INFO ARTIKEL}

\section{Riwayat Artikel:}

Diterima: 16 - 04- 2018

Disetujui: 28 - 06- 2018

\section{Kata Kunci:}

Pembelajaran berbasis masalah

Sikap berpikir kritis

\section{ABSTRAK}

\begin{abstract}
Abstrak: IPA terdiri dari tiga dimensi yang saling terkait yaitu sikap ilmiah, keterampilan proses dan pengetahuan. Transfer pengatahuan lebih mendominasi, sehingga penelitian ini bertujuan untuk meningkatkan sikap berpikir kritis siswa SD melalui penerapan pembelajaran berbasis masalah. Metode penelitian yang digunakan adalah tindakan kelas (PTK). Subjek dalam penelitian ini siswa kelas V di SDN 46 Mataram Tahun pelajaran 2017/2018 yang berjumlah 27 orang. Teknik pengumpulan data menggunakan teknik tes, observasi, dan wawancara. Teknik analisis data yang digunakan adalah analisis diskriptif interaktif. Berdasarkan hasil penelitian dapat disimpulkan bahwa pada siklus I jumlah siswa yang memperoleh nilai $\geq 70$ pada kondisi awal sebanyak 9 siswa (33\%). Selanjutnya meningkat pada siklus I, dimana siswa yang memperoleh nilai $\geq 70$ sebanyak 17 siswa (63\%), dan meningkat tajam pada siklus II, dimana siswa yang memperoleh nilai $\geq 70$ sebanyak 24 siswa (89\%). Berdasarkan hasil analisis data menggunakan gain standar rumus Hake, nilai sikap kritis lebih $>0,3$ sehingga termasuk dalam kategori sedang $(0,3)$. Berdasarkan hasil penelitian, sikap berpikir kritis siswa sekolah dasar dapat dilakukan melalui proses pembelajaran yang bermakna bagi siswa dan melalui proses pembiasaan yang rutin.
\end{abstract}

\section{A. LATAR BELAKANG}

Setiap bidang ilmu pengetahuan memiliki nilai-nilai penting yang menjadi perhatian siswa. Pada pembelajaran IPA, nilai-nilai tersebut terdapat dalam sikap ilmiah. Sikap ilmiah (scientific attitude) dibedakan dari sekedar sikap (attitude) terhadap suatu objek, dalam hal ini adalah sikap terhadap IPA. Sikap ilmiah merupakan aspek tingkah laku yang tidak diajarkan pada suatu pembelajaran, akan tetapi tingkah laku yang diperoleh melalui contoh-contoh positif berkenaan dengan proses yang dilakukan, sehingga dapat diubah atau dibentuk melalui proses belajar.

Sikap ilmiah dapat dimulai dengan adanya beberapa masalah yang meragukan atau membingungkan siswa sehingga mereka dapat menyadari keterbatasan pengetahuan, memiliki rasa ingin tahu untuk menggali berbagai pengetahuan baru dan akhirnya mengaplikasikannya dalam kehidupan. Sikap ilmiah tersebut dapat dikembangkan ketika siswa melalui berbagai kegiatan nyata dengan alam sehingga memungkin terjadinya proses yang aktif dan kritis.

IPA merupakan cara mencari tahu tentang alam sekitar secara sistematis. Berkenanaan dengan proses pembelajaran, IPA mengarahkan pada proses kebiasaan berpikir ilmiah dan berpikir kritis untuk mencari tahu sehingga siswa memperoleh pemahaman yang lebih tentang fenomena dan perubahan-perubahan di lingkungan sekitar dirinya. Salah satu pembelajaran yang terkait dengan proses berpikir ilmiah dan mendukung siswa untuk mampu bersikap ilmiah adalah pembelajaran berbasis masalah. Pembelajaran berbasis masalah merupakan salah pembelajaran yang cocok untuk diterapkan dalam pembelajaran IPA, karena berdasarkan pada masalah-masalah yang dihadapi siswa di lingkungan sekitar. Masalah yang dimaksud bersifat nyata atau sesuatu yang menjadi pertanyaan pelik bagi siswa.

Pada dasarnya dalam kehidupan sehari-hari manusia selalu dihadapkan dengan berbagai masalah yang perlu dipecahkan. Pemecahan masalah dipandang sebagai suatu proses untuk menemukan kombinasi dari sejumlah aturan yang dapat diterapkan dalam upaya mengatasi situasi (Made Wena, 2014; 52). Oleh karena itu, IPA diperlukan dalam kehidupan sehari-hari untuk memenuhi kebutuhan manusia melalui pemecahan masalah-masalah yang dapat diidentifikasikan. Penerapan IPA perlu dilakukan secara bijaksana untuk menjaga dan memelihara kelestarian lingkungan sekitar. Melalui kemampuan memecahkan masalah, siswa mampu menggunakan kemampuan tersebut untuk 
menghadapi tantangan kehidupan secara mandiri, T cerdas, kritis, rasional, dan kreatif.

Pendidikan dasar memiliki tanggung jawab untuk meletakkan dasar-dasar pendidikan bagi seorang manusia agar dapat menjadi pribadi yang berakhlak mulia dan mandiri dalam menghadapi proses kehidupannya. Maslichah Asy'ari (2006: 38) mengemukakan bahwa siswa sekolah dasar mempunyai rasa ingin tahu yang tinggi, siswa bereaksi secara positif terhadap unsur-unsur yang baru, aneh, tidak layak, atau misterius dalam lingkungannya dengan bergerak ke arah benda tersebut, memeriksanya, atau mempermainkannya. Hal ini berarti bahwa siswa sekolah dasar berpotensi untuk memiliki sikap ilmiah.

Siswa sekolah dasar merupakan aset bangsa yang harus dipersiapkan dengan baik sejak dini, karena mereka kelaklah keberlangsungan atau kepunahan kehidupan yang akan datang. Sikap ilmiah yang menjadi perhatian dalam penelitian adalah terbatas pada sikap berpikir kritis khususnya terhadap lingkungan. Tidak hanya dilingkungan masyarakat umum, dilingkungan sekolah juga mulai dijumpai dengan ditandai sering ditemuinya sikap dan perilaku siswa yang membuang sampah sembaragan tanpa berpikir akan akibatnya kelak. Hal ini menandakan bahwa siswa tidak lagi berpikir kritis dan sensitif terhadap lingkungan sekitar. Oleh karena itu penanaman sikap ilmiah harus dilakukan dalam kegiatan pembelajaran khususnya sejak sekolah dasar agar siswa mampu menghadapi setiap permasalahan di dalam hidupnya.

\section{B. METODE PENELITIAN}

Metode penelitian yang digunakan adalah tindakan kelas (PTK). Subjek dalam penelitian ini siswa kelas V di SDN 46 Mataram Tahun pelajaran 2017/2018 yang berjumlah 20 orang. Teknik pengumpulan data menggunakan teknik wawancara, observasi, tes dan dokumentasi. Teknik analisis data yang digunakan adalah analisis diskriptif interaktif. Dimana peneliti ini menggunakan dua siklus, setiap siklus terdiri dari empat tahap yaitu perencanaan, pelaksanaan, observasi dan refleksi. Alat Pengumpulan Data yang diperlukan adalah skor dari nilai hasil belajar, dan lembar observasi berpikir kritis siswa. cara pengumpulan data dengan tes tindakan dan pengamatan, instrumen pengumpulan data berupa butir soal dan lembar pengamatan tertutup. penskoran untuk menghitung skor rata-rata kelas, dengan rumus berikut;

$$
S R=\frac{F i x X_{i}^{i}}{n}
$$

Keterangan :

$$
\begin{array}{ll}
\mathrm{SR} & =\text { Skor rata-rata kelas } \\
\mathrm{Fi} & =\text { jumlah siswa yang memperoleh nilai } \\
\text { rentangan } & \\
\mathrm{Xi} & =\text { Rata-rata nilai rentangan } \\
\mathrm{N} & =\text { Jumlah siswa }
\end{array}
$$

Selanjutnya untuk mengetahui persentase siswa yang sudah tuntas belajar secara klasikal digunakan rumus :

$$
P K K=\frac{T}{N} \times 100 \%
$$

Keterangan :

PKK $\quad$ Persentase ketuntasan klasikal
$=$ Banyak siswa yang mendapatkan nilai $\geq 70$

= Banyak siswa yang diteliti

Secara individu dikatakan tuntas belajar jika $\mathrm{SR} \geq$ 70 dan suatu kelas dikatakan tuntas apabila $\mathrm{PKK} \geq 80 \%$. Data observasi meliputi data sikap berpikir kritis siswa dapat dianalisis dengan menggunakan rumus: (Hake, 1998:3)

$$
\text { Gain }=\frac{\text { skor postes }- \text { skor pretes }}{\text { skor maksimum }- \text { skor pretes }}
$$

Klasifikasi gain standar sebagai berikut:
a) g tinggi : $(\mathrm{g})>0,7$
b) g sedang
$: 0,3>(\mathrm{g})>0,7$
c) g rendah
$:(\mathrm{g})<0,3$

\section{HASIL DAN PEMBAHASAN}

Penetapan SDN 46 Mataram sebagai lokasi penelitian karena terletak didekat Kali Jangkok sehingga memungkinkan siswa melihat secara langsung aktivitas masyarakat sekitar yang berhubungan dengan kali

\begin{tabular}{|c|c|c|c|c|c|c|}
\hline No & $\begin{array}{c}\text { Interval } \\
\text { Nilai }\end{array}$ & $\begin{array}{l}\text { Fre. } \\
\text { (fi) }\end{array}$ & $\begin{array}{c}\text { Nilai } \\
\text { Tengah } \\
\text { (xi) }\end{array}$ & fi.xi & $\%$ & Ket. \\
\hline 1 & $90-100$ & 0 & 0 & $\mathrm{O}$ & $\mathrm{O}$ & - \\
\hline 2 & $79-89$ & 4 & 84 & 336 & 15 & $\begin{array}{l}\text { Diatas } \\
\text { KKM }\end{array}$ \\
\hline 3 & $68-78$ & 5 & 73 & 365 & 19 & $\begin{array}{l}\text { Diatas } \\
\text { KKM }\end{array}$ \\
\hline 4 & $57-67$ & 6 & 62 & 372 & 22 & $\begin{array}{c}\text { Dibawah } \\
\text { KKM }\end{array}$ \\
\hline 5 & $46-56$ & 7 & 51 & 357 & 26 & $\begin{array}{c}\text { Dibawah } \\
\text { KKM }\end{array}$ \\
\hline 6 & $35-45$ & 5 & 40 & 200 & 19 & $\begin{array}{c}\text { Dibawah } \\
\text { KKM }\end{array}$ \\
\hline \multicolumn{2}{|c|}{ Jumlah } & 27 & & 1630 & 100 & \\
\hline \multicolumn{5}{|c|}{ Nilai rata-rata $=1630: 27=60.4$} & & \\
\hline
\end{tabular}
jangkok khususnya kesadaran masyarakat terhadap lingkungan sekitar. Dengan demikian, peneliti dapat melihat secara langsung kebiasaan siswa terhadap lingkungan, dimana masyarakat yang menjadi role model mereka.

TABEL 1.

Data Frekuensi Nilai Kemampuan Berpikir Kritis Siswa

Berdasarkan rumus ketuntasan belajar siswa secara klasikal diperoleh: $\mathrm{PKK}=(9: 27) \times 100 \%=33 \%$. Berdasarkan hasil perhitungan maka dapat diketahui bahwa dari 27 orang siswa sebanyak 18 orang siswa atau sekitar $67 \%$ yang mendapatkan hasil belajar rendah atau tidak tuntas, dan sebanyak 9 orang siswa atau sekitar $33 \%$ yang masuk dalam katagori tuntas belajar terkait dengan kemampuan berpikir kritis siswa pada tema manusia dengan lingkungan.

Dari tabel 1. menunjukkan kemampuan berpikir kritis khususnya terkait dengan lingkungan siswa masih rendah yaitu dengan rata-rata kelas 60,4 untuk itu perlu dilakukan perencanaan untuk melanjutkan siklus I. Setelah diberi perlakuan selama beberapa pertemuan, data frekuensi nilai kemampuan berpikir kritis siswa dapat dilihat pada tabel 2 dibawah ini. 
TABEL 2.

Data Frekuensi Nilai Kemampuan Berpikir Kritis Siswa Pada Siklus I

\begin{tabular}{|c|c|c|c|c|c|c|}
\hline No & $\begin{array}{c}\text { Interval } \\
\text { Nilai }\end{array}$ & $\begin{array}{l}\text { Fre. } \\
\text { (fi) }\end{array}$ & $\begin{array}{c}\text { Nilai } \\
\text { Tengah } \\
\text { (xi) }\end{array}$ & fi.xi & $\%$ & Ket. \\
\hline 1 & $90-100$ & 2 & 95 & 190 & 7 & $\begin{array}{c}\text { Diatas } \\
\text { KKM }\end{array}$ \\
\hline 2 & $79-89$ & 4 & 84 & 336 & 15 & $\begin{array}{c}\text { Diatas } \\
\text { KKM }\end{array}$ \\
\hline 3 & $68-78$ & 11 & 73 & 803 & 41 & $\begin{array}{c}\text { Diatas } \\
\text { KKM }\end{array}$ \\
\hline 4 & $57-67$ & 5 & 62 & 310 & 19 & $\begin{array}{c}\text { Dibawah } \\
\text { KKM }\end{array}$ \\
\hline 5 & $46-56$ & 3 & 51 & 153 & 11 & $\begin{array}{c}\text { Dibawah } \\
\text { KKM }\end{array}$ \\
\hline 6 & $35-45$ & 2 & 40 & 80 & 7 & $\begin{array}{c}\text { Dibawah } \\
\text { KKM }\end{array}$ \\
\hline & Jumlah & 27 & & 1872 & 100 & \\
\hline \multicolumn{7}{|c|}{ Nilai rata-rata $=1872: 27=69,3$} \\
\hline & Ketuntas & n Klasi & $\mathrm{kal}=(17:$ & 7) $\times 10$ & $0 \%=$ & $63 \%$ \\
\hline
\end{tabular}

Berdasarkan rumus ketuntasan belajar siswa secara klasikal diperoleh: $\mathrm{PKK}=(17: 27) \times 100 \%=63 \%$. Berdasarkan hasil perhitungan maka dapat diketahui bahwa dari 27 orang siswa sebanyak 10 orang siswa atau sekitar $37 \%$ yang mendapatkan hasil belajar rendah atau tidak tuntas, dan sebanyak 17 orang siswa atau sekitar $63 \%$ yang masuk dalam katagori tuntas belajar terkait dengan kemampuan berpikir kritis siswa pada tema manusia dengan lingkungan.

Sesuai hasil temuan selama proses pembelajaran siklus I, ada beberapa hambatan dalam prosesnya. Berdasarkan hasil observasi yang dilakukan selama proses pelaksanaan tindakan, peneliti menemukan bahwa kemauan siswa untuk menerima pelajaran masih kurang terlihat, siswa masih belum begitu antusias terhadap pembelajaran yang dilaksanakan, siswa kurang aktif menjawab pertanyaan guru karena masih saja mengobrol dengan teman lain di luar materi pelajaran dan keberanian siswa maju menyampaikan pendapat masih rendah. Dalam proses pembelajaran, siswa kurang mendapatkan kesempatan untuk menganilisis materi dikaitkan dengan fakta yang ada sesuai lingkungannya sehingga siswa kurang membiasakan diri untuk berpikir kritis. Selain itu, masih banyak siswa yang sering membuang sisa makanan disembarang tempat.

Dengan demikian dapat direnungkan bahwa penelitian dalam siklus I belum menunjukkan keberhasilan dalam proses pembelajaran. Berdasarkan permasalahan yang telah dipaparkan di atas, maka peneliti mencari solusi dengan memberikan arahan kembali kepada siswa tentang mengkaitkan materi dengan apa yang mereka lihat dilingkungan sekitar, dan menceritakan kembali di kelas sesuai dengan apa diketahui. Pada saat pembelajaran peneliti meminta siswa maju untuk menyampaikan kondisi lingkungan tempat tinggal khususnya yang dekat dengan kali jangkok. Selain itu, peneliti memberikan konsep lingkungan dan hubungan dengan aktivitas makhluk hidup.

Berdasarkan hasil temuan diatas, walaupun keberhasilan proses belajar mengajar pada siklus I
Haifaturrahmah, Efektivitas Pembelajaran Berbasis...

belum sesuai dengan target nilai yang ingin dicapai yaitu target nilai ketuntasan di atas $80 \%$. Untuk itu peneliti melakukan penelitian sampai hasil belajar mengalami perubahan kepada kategori ketuntasan. Sehingga perlu diadakan kembali perbaikan pembelajaran yang memungkinkan dapat memaksimalkan hasil belajar siswa maka dilanjutkan pelaksanaan siklus II.

Data frekuensi nilai kemampuan berpikir kritis siswa siklus dapat dapat dilihat pada tabel 3 dibawah ini.

TABEL 3 .

Data Frekuensi Nilai Kemampuan Berpikir Kritis Siswa Pada Siklus Ii

\begin{tabular}{|c|c|c|c|c|c|c|}
\hline No & $\begin{array}{c}\text { Interval } \\
\text { Nilai }\end{array}$ & $\begin{array}{l}\text { Fre. } \\
\text { (fi) }\end{array}$ & $\begin{array}{l}\text { Nilai } \\
\text { Tengah } \\
\text { (xi) }\end{array}$ & fi.xi & $\%$ & Ket. \\
\hline 1 & $90-100$ & 6 & 95 & 570 & 22 & $\begin{array}{l}\text { Diatas } \\
\text { KKM }\end{array}$ \\
\hline 2 & $79-89$ & 10 & 84 & 840 & 37 & $\begin{array}{l}\text { Diatas } \\
\text { KKM }\end{array}$ \\
\hline 3 & $68-78$ & 8 & 73 & 584 & 30 & $\begin{array}{l}\text { Diatas } \\
\text { KKM }\end{array}$ \\
\hline 4 & $57-67$ & 2 & 62 & 124 & 7 & $\begin{array}{c}\text { Dibawah } \\
\text { KKM }\end{array}$ \\
\hline 5 & $46-56$ & 1 & 51 & 51 & 4 & $\begin{array}{c}\text { Dibawah } \\
\text { KKM }\end{array}$ \\
\hline 6 & $35-45$ & 0 & 40 & 0 & o & $\begin{array}{c}\text { Dibawah } \\
\text { KKM }\end{array}$ \\
\hline & Jumlah & 27 & & 2169 & 100 & \\
\hline \multicolumn{7}{|c|}{ Nilai rata-rata $=2169: 27=80,3$} \\
\hline
\end{tabular}

Berdasarkan rumus ketuntasan belajar siswa secara klasikal diperoleh: PKK $=(24: 27) \times 100 \%=89 \%$. Berdasarkan hasil perhitungan maka dapat diketahui bahwa dari 27 orang siswa sebanyak 3 orang siswa atau sekitar $11 \%$ yang mendapatkan hasil belajar rendah atau tidak tuntas, dan sebanyak 24 orang siswa atau sekitar $89 \%$ yang masuk dalam katagori tuntas belajar terkait dengan kemampuan berpikir kritis siswa pada tema manusia dengan lingkungan.

Dari tabel 3 di atas, maka peneliti mengulas bahwa berdasarkan indikator kinerja yang ditetapkan, peneliti dikatakan berhasil bila hasil belajar siswa untuk mengukur kemampuan berpikir kritis secara individu menunjukkan sekurang-kurangnya 70 dan klasikal menunjukkan $80 \%$. Dilihat dari nilai rata-rata kelas pembelajaran berbasis masalah terkait dengan manusia dan lingkungan dikatakan sudah berhasil, dimana jumlah siswa secara individu yang mendapatkan nilai sekurang-kurangnya 70 (KKM) sudah mencapai $80 \%$ dan secara klasikal nilai rata-rata siswa dikategorikan lebih dari cukup. Dari fakta tersebut maka penelitian tindakan kelas ini dianggap cukup dan diakhiri pada siklus II.

Peningkatan terlihat dari perhitungan rata-rata nilai belajar yang diperoleh siswa setelah dilaksanakan tindakan siklus I dan siklus II yang masing-masimg siklusnya dilaksanakan dua kali pertemuan. Hal ini dapat dilihat pada tabel 4 seperti berikut: 
TABEL 4.

Rerata Nilai Kemampuan Berpikir Kritis Siswa

\begin{tabular}{ccc}
\hline No & Deskripsi Nilai & Rerata \\
\hline 1 & Pra siklus & 60,4 \\
2 & Siklus I & 69,3 \\
3 & Siklus II & 80,3 \\
\hline
\end{tabular}

Untuk mengetahui lebih lanjut mengenai peningkatan skor berpikri kritis siswa melalui observasi berdasarkan perhitungan gain, maka peneliti merangkum hasil perolehan gain skor siklus I dan siklus II pada tabel 5 dibawah ini.

TABEL 5 .

Rerata Giant Kemampuan Berpikir Kritis Siswa

\begin{tabular}{cccc}
\hline Variabel & $\begin{array}{c}\text { Siklus } \\
\text { I }\end{array}$ & $\begin{array}{c}\text { Siklus } \\
\text { II }\end{array}$ & $\begin{array}{c}\text { Gain } \\
\text { Standar }\end{array}$ \\
\hline $\begin{array}{c}\text { Bepikir } \\
\text { kritis }\end{array}$ & 22,60 & 25,10 & 0,31 \\
\hline
\end{tabular}

Dari Tabel 5 diatas, nilai gain standar sikap berpikir kritis berada dalam kategori rendah. Meskipun demikian, terjadi peningkatan sebesar 2.50 poin. Berdasarkan hasil observasi di beberapa kelas yang berbeda, dapat disimpulkan bahwa kegiatan belajar siswa lebih terfokus untuk mencatat dan mendengarkan, sehingga proses pembentukan sikap khususnya berpikir kritis kurang maksimal melalui proses pembelajaran yang digunakan selama ini.

Dalam pembelajaran IPA, sikap berpikir kritis dibutuhkan untuk menganalisis gejala-gejala maupun fenomena-fenomena yang muncul dilingkungan sekitar. Berpikir kritis adalah sebuah proses sistematis saat siswa membuat suatu keputusan tentang apa yang ia percaya dan kerjakan (Ennis, 1996), sehingga memungkinkan siswa untuk merumuskan, mengevaluasi keyakinan dan pendapat mereka sendiri. Dimana sikap berpikir kritis akan memotivasi siswa untuk merefleksi terkait apa yang telah dilakukan dan mengenai ide yang muncul selama kegiatan pembelajaran berlangsung. Menurut Patta Bundu (2006:42) refleksi yang dilakukan oleh siswa memberikan kesempatan kepada siswa untuk menyampaikan beberapa alternatif dalam sutau solusi pemecahan masalah dan kemudian memunculkan sikap berani mengemukakan pendapat yang berbeda dari teman sekelasnya berdasarkan dari data serta fakta yang ia temukan. Pada akhirnya, siswa akan terbiasa untuk memilah-milah informasi dengan argumen yang logis sesuai dengan fakta.

\section{KESIMPULAN DAN SARAN}

1. Simpulan

Berdasarkan hasil penelitian dapat disimpulkan bahwa penggunaan pembelajaran berbasis masalaha dapat meningkatkan sikap berpikir kritis siswa dan hasil belajar pada siswa kelas V SDN 46 Mataram tahun pelajaran 2017/ 2018. Meskipun demikian, berdasarkan hasil data giant standar, sikap berpikir kritis siswa masih dalam kategori sedang. Hal ini terkait dengan proses pembiasaan yang dilakukan oleh guru terhadap siswa melalui pembelajaran didalam kelas. karena, proses pembiasaan siswa untuk mampu berpikiri kritis dan menjaga lingkungan membutuhkan waktu.

2. Saran

IPA terdiri dari tiga dimensi yang saling terkait yaitu sikap ilmiah, keterampilan proses dan pengetahuan. Seyogyanya, proses pembelajaran memperhatikan karakteristik perkembangan siswa sekolah dasar tanpa mengurangi kualitas maupun kuantitas aspek dalam pendidikan. Dengan demikian, semua pengetahuan maupun keterampilan yang dimiliki oleh siswa akan memiliki makna bagi diri sendiri dan lingkungan sekitarnya.

\section{DAFTAR RUJUKAN}

[1] Abruscato, J. (1995). Teaching children science: A discovery approach. (4 ${ }^{\text {th }}$ ed). Boston: Allyn and Bacon, inc.

[2] Anderson, Lorin W. (1981). Assessing affective characteristics in the schools. Boston: Allyn and Bacon, Inc.

[3] Asep Herry Hernawan., dkk. (2010). Materi pokok: Pengembangan kurikulum dan pembelajaran. (cet.6). Jakarta: Universitas Terbuka.

[4] Baharuddin \& Esa N. W. (2010). Teori belajar dan pembelajara. Yogyakarta: Ar-Ruzz Media.

[5] Collette, A.T., \& Chiappetta, E.L. (1994). Science teaching in the middle and secondary schools. (3rd ed). New York: Maxwell Macmillan, Inc.

[6] Ennis, R.H. 2011. The Nature of Critical Thinking: An Outline of Critical Thinking Dispositions and Abilities. Prentice Hall: University of Illinois.

[7] Hackket, J.K., Moyer, R.H., \& Adams, D.K. (1989). Science. Ohio: Merril Publishing Company.

[8] Hamzah B. Uno. (2012). Perencanaan pembelajaran. Jakarta: Bumi Aksara.

[9] Made Wena. (2014). Strategi pembelajaran inovatif kontemporer. Jakarta: PT. Bumi Aksara.

[10] Maslichah Asy'ari. (2006). Penerapan pendekatan sainsteknologi-masyarakat dalam pembelajaran sains di sekolah dasar. Jakarta: Depdiknas.

[11] Moh. Amien. (1987). Mengajarkan ilmu pengetahuan alam (IPA) dengan menggunakan metode "discovery" dan "inquiry". Jakarta: Depdiknas.

[12] Patta Bundu. (2006). Penilaian keterampilan proses dan sikap ilmiah dalam pembelajaran sain sekolah dasar. Jakarta: Depdiknas.

[13] Shumway R. J. (1980) (Eds.).Research in mathematics education. Reston: National Council Teachers of mathematics.

[14] Sudjana, Nana. (2013). Penilaian Hasil Proses Belajar Mengajar.Bandung:PT Remaja Rosdakarya

[15] Suharsimi Arikunto. (2015). Prosedur Penelitian Suatu Pendekatan Praktek. Jakarta: PT Rineka Cipta

[16] Sugiyono. (2016). Statistik untuk Penelitian. Bandung: Alfabeta.

[17] Wina Sanjaya. (2014). Strategi pembelajaran berorientasi standar proses pendidikan. Jakarta: Kencana Prenada Media Group. 